\title{
Pod Shattering: A Homologous Series of Variation Underlying Domestication and an Avenue for Crop Improvement
}

\author{
Ezgi Ogutcen 1, + , Anamika Pandey $2,+\left[D\right.$, Mohd Kamran Khan ${ }^{2,+}$, Edward Marques ${ }^{3}$, \\ R. Varma Penmetsa ${ }^{4}$ (D), Abdullah Kahraman ${ }^{5}$ and Eric J. B. von Wettberg ${ }^{3, *(D)}$ \\ 1 Department of Plant Sciences, University of Saskatchewan, Saskatoon, SK 57N 5E8, Canada; \\ eogutcen@ucalgary.ca \\ 2 Department of Soil Science and Plant Nutrition, Faculty of Agriculture, Selcuk University, \\ Konya 42079, Turkey; anamika.biotech@gmail.com (A.P.); mohdkamran.biotech@gmail.com (M.K.K.) \\ 3 Department of Plant and Soil Sciences, University of Vermont, Burlington, VT 05405, USA; \\ Edward.Marques@uvm.edu \\ 4 Department of Plant Sciences, University of California Davis, Davis, CA 95616, USA; \\ rvpenmetsa@ucdavis.edu \\ 5 Department of Field Crops, Faculty of Agriculture, Harran University, Sanliurfa 63300, Turkey; \\ kahraman@harran.edu.tr \\ * Correspondence: Eric.Bishop-von-Wettberg@uvm.edu; Tel.: +1-802-6565-9117 \\ + These authors contributed equally to this work.
}

Received: 10 June 2018; Accepted: 1 August 2018; Published: 3 August 2018

\begin{abstract}
In wild habitats, fruit dehiscence is a critical strategy for seed dispersal; however, in cultivated crops it is one of the major sources of yield loss. Therefore, indehiscence of fruits, pods, etc., was likely to be one of the first traits strongly selected in crop domestication. Even with the historical selection against dehiscence in early domesticates, it is a trait still targeted in many breeding programs, particularly in minor or underutilized crops. Here, we review dehiscence in pulse (grain legume) crops, which are of growing importance as a source of protein in human and livestock diets, and which have received less attention than cereal crops and the model plant Arabidopsis thaliana. We specifically focus on the (i) history of indehiscence in domestication across legumes, (ii) structures and the mechanisms involved in shattering, (iii) the molecular pathways underlying this important trait, (iv) an overview of the extent of crop losses due to shattering, and the effects of environmental factors on shattering, and, (v) efforts to reduce shattering in crops. While our focus is mainly pulse crops, we also included comparisons to crucifers and cereals because there is extensive research on shattering in these taxa.
\end{abstract}

Keywords: abscission layer; artificial selection; crop domestication; dehiscence; legumes; seed dispersal

\section{Introduction}

Indehiscent or non-shattering fruits is one of the hallmarks of crop domestication [1]. In wild taxa, dehiscence is crucial for the propagation of offspring and their adaptation under diverse growth conditions. Dispersing seeds from the maternal plant is important, as greater distances generally increase offspring success due to the availability of less competitive environments [2]. In crop plants however, indehiscence is a preferred trait, because dehiscent fruits make harvesting difficult and often lead to significant production losses [3-6]. Therefore, shattering was likely to be one of the first traits strongly selected against by early agriculturalists. Although a critical trait, not all seed crops have completely indehiscent fruits. In order to improve beneficial traits such as disease resistance and stress 
tolerance, breeders are often required to utilize wild crop material, which are prone to shattering [7-9]. Consequently, there is often some degree of shattering in cultivated material, particularly in minor crops. Crop losses at harvest due to shattering can be substantial, especially in some traditional crops with a history of hand harvest, and transition to machine harvesting may further increase these losses. Statistics on crop losses from seeds shattered at harvest have not been thoroughly assembled, so their extent is not well known.

Increasing indehiscence in crops is crucial for higher yield and profitability, and the key to this lies in understanding the genetic basis of shattering in domesticated crops. The genetics of domestication has been studied by botanists for over a century. Darwin had pronounced interest in domestication as a form of artificial selection. He noticed heritable parallel variations in many traits among different crops including cereals and legumes, but shattering was not one of the traits he studied [10]. In his groundbreaking studies of crop species, Vavilov [11,12] also noted similar heritable variations across cultivated taxa, which he called the Law of Homologous Series. Vavilov observed that related taxa share a resemblance in their series of heritable traits, and that the closer the taxa are, the higher the resemblance was found among them [11]. These observations were based on several shared traits, including indehiscence in cereal and legume crops, where wild relatives have dehiscent fruits (or colloquially, dehiscent seeds), and cultivated forms do not.

We have a growing but still incomplete understanding of the genetic basis of shattering in a number of crops (beans [13]; rice [14,15]; lentil [16]; wheat [17]; pea [18]). Much of this evidence suggests that pathways and loci controlling shattering are deeply conserved across taxa, and that homologous mechanisms and loci underlie indehiscence $[19,20]$. As a consequence, these shared domestication-related loci became common targets of breeding programs.

Legumes are important members of nearly all agricultural systems, as well as one of the most diverse and ecologically important botanical families [21,22]. With their capacity for symbiotic nitrogen fixation, they are important sources of dietary protein, and important members of crop rotations or inter-cropping schemes. Declining utilization of legumes in crop rotations and their declining consumption following the green revolution contributes to dietary imbalances such as protein and micronutrient deficiencies, and unnecessary reliance on synthetic nitrogen inputs into agricultural systems and the pollution that entails [23-25]. Legumes, along with cereals, were some of the most ancient domesticated crops in each of the regions where agriculture arose independently (i.e., Vavilovian centers of domestication). In addition to early domestications (such as Phaseolus vulgaris L., Cicer arietiunum L., Pisum sativum L., and Glycine max (L.) Merr.), legumes have continued to be domesticated as agriculture has expanded and intensified, with more recent domestications such as pigeonpea (Cajanus cajan (L.) Millsp.) and mungbean (Vigna radiata (L.) R. Wilczek) around 4000 years ago in South Asia [26,27], alfalfa domesticated in Roman times [28] (Medicago sativa L.), and narrow-leaved lupin (Lupinus angustifolius L.) domesticated as a sweet lupin over the past century [29]. For a few legumes, such as fava bean, Vicia faba L., the nature of domestication has been obscured by the absence of a known compatible wild relative, although archeological evidence is starting to clarify at the least the chronology of domestication [30,31].

Despite of the detailed reporting of the domestication, there has been a lack of comprehensive literature review on pulse crop shattering. Focusing on shattering in pod bearing crops, this review aims to provide (i) a review of the significance of indehiscence in the domestication across legumes and other taxa, (ii) an overview of the mechanisms and anatomical structures that underlie shattering, (iii) a synopsis of the genes and pathways that control this important trait, (iv) an summary of the limited information available on the extent of crop losses due to shattering, and how environmental factors impact shattering, and (v) finally a preview of emerging efforts to reduce shattering in crops. While our primary focus is pulse crops, we have also included crucifers in this review, because there is extensive research on shattering in the Brassicaceae, which have a pod shattering mechanism similar to legumes. We have also reviewed some examples from other shattering-prone crops such as cereals. 


\section{Milestone in Plant Domestication: Pod Shattering as Part of the Domestication Syndrome}

Plant domestication is one of the most important advancements of the Neolithic Revolution, during which human cultures started transitioning from hunter and gatherer lifestyles to agriculture-oriented settlements [32,33]. Crop domestication started about 13,000-10,000 years ago in the Middle East and the Fertile Crescent, and occurred soon after in other regions including South Asia, Mesoamerica, the Andes, Near Oceania (10,000 years ago); sub-Saharan Africa (8000 years ago); and eastern North America (6000 years ago) [32]. Over 2500 species from 160 plant families have been domesticated [34]. Legumes and cereals however appear repeatedly as domesticates in different regions. Regions with agricultural development, i.e., domestication centers, vary greatly in terms of which species are domesticated and how much a genetic variation is preserved during the domestication process, depending on the breeding systems of the crops, local geography and the people's need in the region [35]. There has long been debate over the speed of domestication, with opinions varying from a protracted and largely unintentional process to rapid and very deliberate one [3]. In addition to variation in the speed of domestication, domesticated crops can also have multiple or parallel domestication events, which contributes to the phenotypical diversity of modern crops today (e.g., Phaseolus vulgaris L. [36,37]).

Domestication is often described as a multi-step process. The earliest farmers utilized the genetic variation present in the wild progenitors and selected individuals with favorable traits, improving the crop population $[35,38,39]$. With selection and breeding, desirable traits in crop populations and crop varieties started to increase. After the initial stages of domestication, many crops experienced range expansions via human migrations and trade, and the limits to their present distribution are influenced by environmental factors [33]. After domestication, deliberate breeding of crops further leads to divergence of post-domestication traits, and improves yield and resilience in modern crops [4,34]. The initial stage of domestication left its imprint in current crop populations due to the fact that the early domestication efforts used a limited number of progenitors, which decreased the genetic diversity of the crop species [35]. During domestication, the overall genetic diversity is reduced, and the effect is more pronounced in domestication-related genes as they are exposed to severe genetic bottlenecks due to strong selection [39].

The domestication syndrome is a collection of desirable characteristics associated with the domestication of crops from their wild progenitors $[35,38]$. The set of domestication traits and their importance vary among different crops, but the most common traits include loss of seed dormancy, increase in fruit/seed size, erect growth habit, reduced toxins, earlier and more uniform flowering, and loss of seed dispersal [34]. The domestication syndrome for pulses is similar to that of cereals, and includes increased seed size, loss of shattering, and loss of germination inhibition [40]. In addition to these traits that were likely directly selected, other aspects of legumes also changed, perhaps inadvertently as side-effects or as selection for greater palatability, such as shifts in mineral content, declines in carotenoid values [41] and increases in tryptophan levels [42]. Likely the importance of and the order of selection for domestication traits differ between pulses and cereals, and the role of intentional vs. unintentional selection has long been debated [3,43].

Domestication traits confer advantages in terms of ease of harvest, survival in varying environments, and increased yield. These traits may decrease fitness in the wild but are preferred under human exploitation [35]. One such trait, pod shattering, is an essential mechanism in wild legumes to spread their seeds and facilitate their propagation and reproduction. Greater dispersal distances generated by shattering seeds are more likely to place seeds in more distant microsites, away from pathogens and pests of the maternal plant and competition from siblings. From the agronomic perspective on the other hand, the natural propensity for seed dispersal is an undesired trait in crops as it leads to substantial yield losses and inefficient harvesting [39]. Upon acquiring pod indehiscence, the survival of the crop depends on a symbiosis with a farmer, as the seeds must be dispersed by human labor. Consequently, natural seed dispersal was likely severely selected against by early farmers in the domestication process to assure efficient harvesting [34]. The loss of shattering renders 
domesticated crops more dependent on human activity for propagation, and it further facilitates the fixation of other domestication characters, making it an important milestone in the domestication process [33].

Several studies demonstrated shattering resistance can be gained by mutations in a single locus (common vetch [44]; common bean [45]; azuki bean [46]; lentil [47]), or in two loci (narrow-leaf lupin [48]; soybean [49]; cowpea [50]; pea [51]). Interestingly, in common bean, where the St locus controls shattering, the Arabidopsis Indehiscent gene occurs near the locus, but does not co-segregate with indehiscence, suggesting that more fine-mapping is needed to localize the causative gene [45]. Nevertheless, throughout the domestication process, strong selection of indehiscence loci leads to the fixation of non-shattering traits in crop plants [33], and consequently, a number of modern cultivars have indehiscent pods. However, further advancement is still required, especially in regions with adverse climatic conditions and delayed harvesting, and in crops that have pods that are only partially indehiscent. Furthermore, more work is needed to determine if the alleles conferring indehiscence arose before domestication and remained at low frequency in natural populations or were new mutations that occurred during the process of domestication.

\section{Structures Involved in Shattering}

Abscission is the detachment of entire organs from a plant, (e.g., dropping of dead leaves, or ripe fruit), whereas dehiscence is the release of an organ's internal contents (e.g., release of seeds from a fruit, or pollen grains from anthers). Abscission and dehiscence occur at specific areas with narrow bands of differentiated cells, called abscission and dehiscence zones, respectively. Both processes involve cell-cell separation by dissolution of the intercellular adhesive substances and degradation of the cell wall [52].

In general terms, shattering is the release of the seeds from a dry fruit upon maturation, but it stands for different processes in different taxa: in cereals, it is the detachment of the fruit from the pedicel; while in legumes and crucifers, it refers to the opening of the pod or the silique, which causes seeds to be released $[53,54]$. The process of shattering differs among crops. Therefore, different anatomical structures and mechanisms are involved in the process [55].

Most of the studies on dehiscence and the structures involved in the process have been conducted on Arabidopsis thaliana, a model species from the family Brassicaceae. Members of the crucifer family produce a silique, a dry dehiscent fruit that consists of two fused carpels (Figure 1). The septum extends along the center of the silique and forms a division line between the two fused carpels. The seeds are enclosed in between the two valves, and they are attached to the septum through the placenta. The septum is connected to the inner walls of the valves at both sides through the replum. The replum, also known as false septum, is a thin layer separating the two valves of the silique along both sides, and it contains the main vascular bundles [56]. The valves are differentiated into several layers with different structures (Figure 1D,E): the exocarp is the outermost layer with long and broad epidermal cells, the mesocarp is the middle layer with parenchymal cells, and the endocarp is the innermost layer with two distinct regions; endocarp $a$, and endocarp $b$ [56]. The valve cells are smaller at the connection point near the replum, forming valve margins with two narrow layers running through the whole length of the silique; one where cell separation occurs, and another one with lignified cells that provides a spring-like action to facilitate the opening of the silique (Figure 1D,E, [52]). Collectively called the dehiscence zone, this region is where the dehiscence process occurs towards the end of silique development [57]. 
A

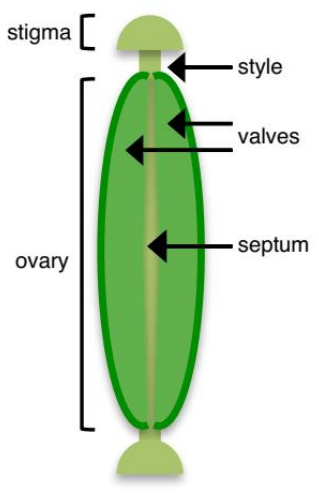

B

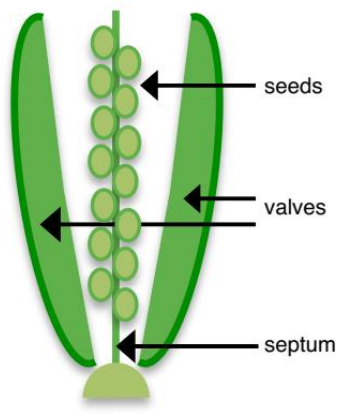

C

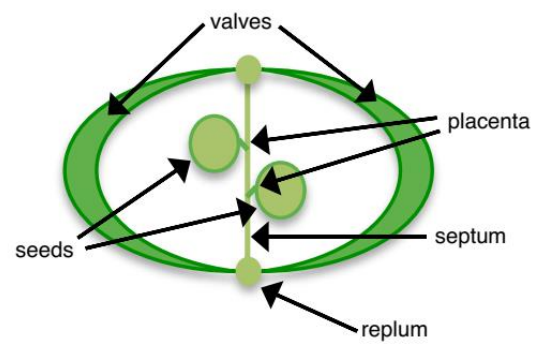

D

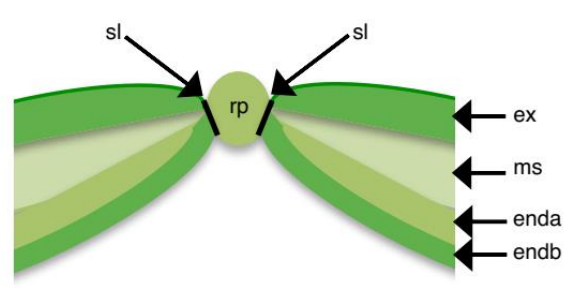

E

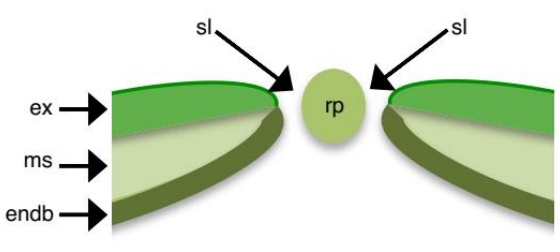

Figure 1. Structure of the Arabidopsis silique, (A) Before dehiscence, the silique is intact, and enclosing the seeds. (B) Seeds are attached to the septum through the placenta within the valves. (C) Cross section of the silique inside the valves. (D,E) Magnified view of the replum region. sl: separation layer; rp: replum; ex: exocarp; ms: mesocarp; enda: encodarp a; endb: endocarp b. (D) Cells near the replum are smaller and more dense, forming a visible separation layer. (E) As dehiscence progresses, endocarp a disintegrates and endocarp b lignifies (shown in darker green). The figure is derived from [56,58].

During the silique dehiscence process, while endocarp a layer undergoes programmed cell death and starts to disintegrate, endocarp $b$ layer goes through cell wall lignification [58]. Once lignification is complete, valve attachment becomes weakened, and cell walls within the dehiscence zone start to degrade due to the breakdown of middle lamella by the enzymatic activity of endopolygalacturonase [59]. These processes however, are not sufficient for silique to open; physical stress coupled with desiccation is necessary to induce silique shattering [60,61]. The rigidity of the lignified endocarp $b$ layer assists the shattering process by providing a spring-like tension within the silique, causing it to split open to release the seeds [57]. In Brassica, increased lignin deposition was shown to be correlated with shatter susceptibility [60], and increased vascular tissue and the decreased cell wall degradation within the dehiscence zone were associated with dehiscence-resistance in Brassica [62].

Several hormones are involved in the regulation of silique dehiscence. Maintaining low levels of auxin in the valve margins is required for the development of the separation layer [63]. Prior to desiccation of Brassica silique, a decrease in auxin content in the valve margins correlates with an increase in B-1,4-glucanase (cellulase) activity, which triggers cell wall degradation [64]. The growth regulator hormone ethylene also plays an important role in the initiation of the dehiscence process. Upon silique maturation, elevated ethylene production causes hydrolytic enzyme activity to increase at the dehiscence zone, promoting the enzymatic degradation of cell wall pectins and the middle lamella 
mediated by cellulase [61]. Cytokinin and gibberellin hormones are also known to play interactive roles in valve margin formation, but their exact functions are yet to be determined [65].

Members of the family Fabaceae produce a pod, a photosynthetically active structure enclosing the seeds (Figure 2). In contrast to the bicarpellate silique in crucifers, the legume pod is derived from a single carpel fused at both sides. This difference between the fruit structure of the two families reflects the origin of the silique and legume; the former has evolved from two leaves merging to enclose the seeds, whereas the latter has evolved from a single leaf, where the leaf folds to cover the seeds [66]. The two halves of the legume pods are connected along the ventral and dorsal sutures, corresponding respectively to the midrib (central rib of the leaf) and the fused margins of a modified leaf. The pod wall consists of an exocarp that has epidermal cells with thickened walls, a mesocarp with parenchymal cells, and an endocarp with sclerenchyma and inner epidermis layers [57]. The vascular bundles develop thick walls at the sutures and the resulting structure is called the bundle cap. The dehiscence zone is located at both sutures, but in the ventral suture, instead of spanning the entire pod wall, the dehiscence zone terminates at the fiber cap cells at the border between the bundle cap and the mesocarp [66].

A

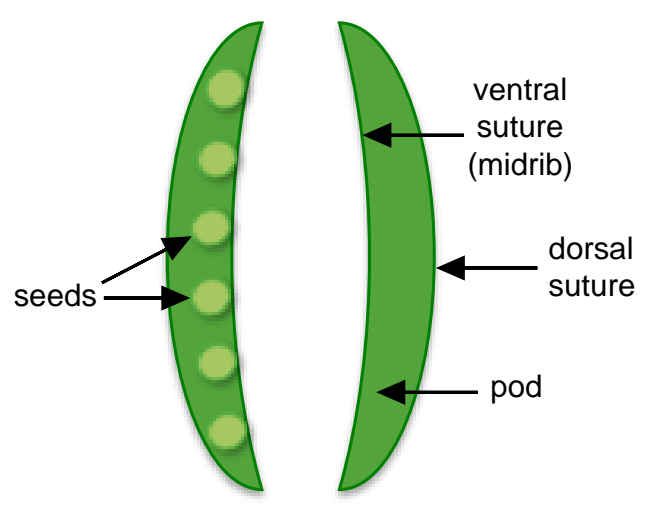

$\mathrm{C}$

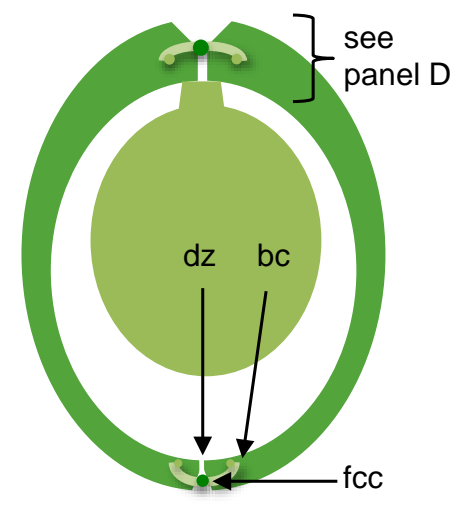

B

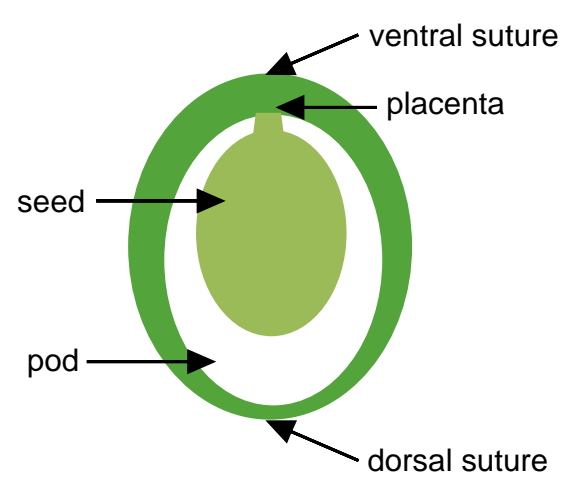

D

ventral

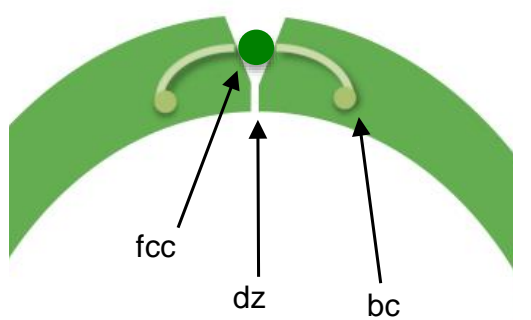

dorsal

Figure 2. Structure of a legume pod. (A) Cross section of the pod in which the seeds are enclosed. (B) Cross section of the pod. Seeds are attached to the midrib through the placenta. (C,D) Magnified views of the cross section. bc: bundle cap, dz: dehiscence zone, fcc: fibre cap cells. The figure is derived from [66]. 
Pod dehiscence is initiated by the weakening of the dorsal and ventral dehiscence zones, and it depends on the cell wall modifying enzyme endopolygalacturonase, which is closely related to the pectin hydrolases involved in silique dehiscence processes in Arabidopsis and Brassica [66,67]. The enzymatic breakdown of middle lamella occurs when the pod reaches maturity and approaches senescence. The senescing cells in the dehiscence zone have large vacuoles, implying that they undergo programmed cell death towards the end of the dehiscence process [66]. The opening of the pod is triggered by the tension built inside the senescing pod, and it occurs on the dorsal side of the pod, as the only structure connecting the valve edges at the dorsal side is the fiber cap cells [68].

Bundle cap length and thickness are negatively correlated with the degree of pod shattering; therefore enlargement of these structures provides mechanical support. This was once thought to confer shattering resistance in soybean [68]. However, more recent characterization of the soybean indehiscence gene SHAT-5 suggests that shattering is controlled by the thickness of the cell walls in the ventral suture of the pod [69] (see below). Thicker bundle caps provide strength to the pod and shorten the sclerenchyma tissue at the sutures, limiting the cleft (fissure or opening) enlargement that occurs prior to shattering [68]. The size of the cleft was correlated with shatter susceptibility, and such cleft was absent in shattering-resistant soybean varieties [68].

\section{Molecular Basis of Shattering}

Although researchers have been emphasizing the importance of shattering for a long time, concerted efforts have been made to identify the genes and mutations associated with this trait only in the past decade $[33,35,70-72]$. There are several mechanistic and genetic routes to indehiscence [73], with some larger effect genes being modulated by smaller effect modifiers. In this section, we start with some examples from cereal crops, which have extensive data on the genetic control of shattering, and then move to pod-bearing legume crops.

\subsection{Shattering in Cereal Crops}

In cereal crops shattering is often referred to as seed shattering rather than fruit shattering, even if large similarities exist with dicotyedonous plants. This usage is widespread, although it is somewhat confusing in that the seed itself does not shatter into pieces, but is the separation of the seed from the maternal plant. Specifically, shattering in cereal crops occurs in a layer of specialized cells, collectively called the abscission zone, between the pedicel and lemma [74]. Studies aimed to understand the molecular mechanisms of shattering in cereal crops have been mainly focused on rice, wheat, and sorghum $[14,15,17,19]$.

In rice (Oryza sativa L.), SH4 (shattering 4) was found to be one of the major quantitative trait loci (QTL) involved in shattering [15]. SH4 is a trihelix transcription factor with a MYB3 binding domain, and it plays an essential role in the abscission layer formation at the early stages of floral development [15]. qSH1 (QTL for shattering 1) is a BEL1-type homeobox gene, and similar to SH4, it regulates shattering via the formation of abscission layer in rice [14]. Shattering abortion 1 (SHAT1) is an AP2 (Apetala2)-like transcription factor responsible for abscission zone differentiation in rice [75]. SHAT1 expression is promoted by SH4, and qSH1 is upregulated by SHAT1 and SH4 to maintain the abscission zone development. Collectively, SH4, SHAT1, and qSH1 are involved in a positive feedback mechanism that maintains the abscission zone development and differentiation [75]. SH5 (Shattering 5) is another BEL-1-type homeobox gene that is homologous to qSH1. SH5 enhances shattering by promoting abscission zone development and repressing lignin synthesis in rice [76]. When expression patterns were examined, qSH1 and SH5 were both found to induce SHAT1 and SH4 expression, but they exert their regulatory effects via different pathways independent from each other [77].

In wheat (Triticum aestivum $L$.), floral homeotic gene $Q$ encodes a transcription factor similar to the APETALA2 (AP2) gene in Arabidopsis [17]. AP2-type genes are involved in a variety of developmental processes, especially flowering and inflorescence structure [77]. Q was found to regulate shattering [17], 
along with several traits including glume shape, plant height, spike length, and emergence time in wheat $[78,79]$.

In sorghum, YABBY ( $\mathrm{C} 2 \mathrm{C} 2$ zinc finger-like domain towards the amino terminus and a helix-loop-helix) transcription factor Shattering1 (SH1) was found to be responsible for shattering, and orthologs of this gene were found in other cereals including rice and maize [19]. Shattering in sorghum was initially thought to be regulated by a single gene, but another gene was found to control shattering in wild sorghum (Sorghum propinquum). SpWRKY is a WRKY transcription factor that modulates flower and seed development and lignin deposition, and it is involved in the shattering process [80].

\subsection{Shattering in Arabidopsis and Other Crucifers}

In A. thaliana, the differentiation of the dehiscence zone is controlled by intricate regulatory networks involving multiple transcription factors [51,63,65,81]. Valve margin identity is developed and maintained via the expression of several transcription factors including the MADS-box genes shatterproof (SHP1), and SHP2, and basic helix-loop-helix genes Indehicent (IND) and Alcatraz (ALC) [82-84]. The activity of these regulatory genes is restricted to the valve margins, as their expression is repressed by REPLUMLESS (RPL) gene in the replum [85], and FRUITFULL (FUL) gene in the valves [86]. Inhibition of FUL activity increases the ectopic expression of IND, SHP1 and SHP2 (collectively called SHP1,2), resulting in indehiscent pods [83].

Upstream of the valve margin development pathway described above, there are three regulatory genes (Figure 3): Two YABBY family transcription factors FILAMENTOUS FLOWER (FIL) and YABBY3 (YAB3), and a C2H2 zinc-finger transcription factor JAGGED (JAG) [87]. FIL and YAB3 regulate tissue polarity, and JAG regulates tissue growth in lateral organs. During the valve margin development, these genes act in concert to promote the expression of FUL in the valves, and SHP1,2 in the valve margin [87]. In the replum, RPL gene downregulates JAG and FIL to repress valve margin development.

The expression of SHP genes is regulated by two more transcription factors. MADS-box gene Agamous $(A G)$, which specifies the formation of stamen and carpel identity in the third and fourth floral whorls respectively, is shown to promote SHP1,2 expression [88]. Apetala2 (AP2) is a transcription factor involved in flower and seed development. During silique maturation in Arabidopsis, AP2 acts as a negative regulator of replum and valve margin growth by inhibiting RPL and SHP1,2 expression, respectively [89].

IND can be considered as the main regulator of valve margin identity as it is involved in several hormonal pathways that promote valve margin identity. The separation layer cells have low auxin response, which is controlled by the transcription factor IND [63]. Auxin response levels are regulated by the PIN family of auxin efflux carriers [90]. Whereas IND does not have a direct effect on PIN expression, it upregulates the expression of Spatula (SPT), and they act together to control auxin distribution [91]. These two transcription factors indirectly regulate PIN by inhibiting the expression of phosphorylase PID, and promoting the expression of kinase WAG2, which controls PIN localization [63]. IND also promotes gibberellin production, which is required for the release of IND from its interaction with DELLA proteins that prevent IND activity [81]. Cytokinin signaling is another dehiscence regulatory mechanism downstream of IND. Even though the exact function of cytokinin is not yet identified, it is suggested that it acts in concert with the auxin and gibberellin hormones to define the valve margin structure [65]. These intertwined pathways suggest multiple levels of hormonal regulation of the valve margin identity. 

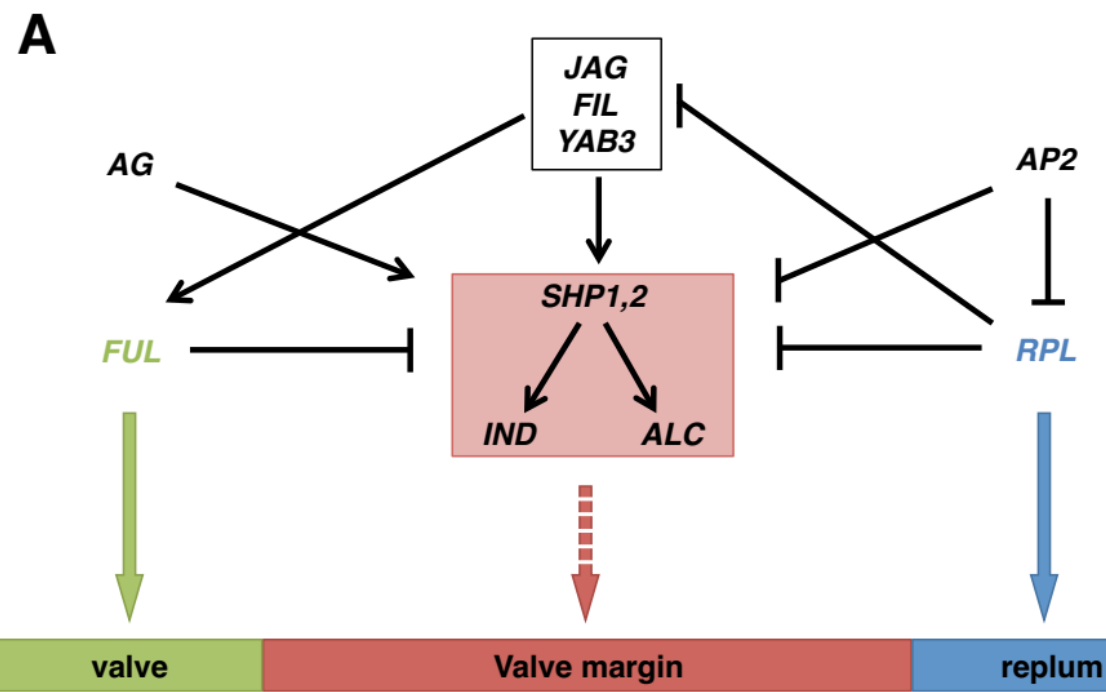

B

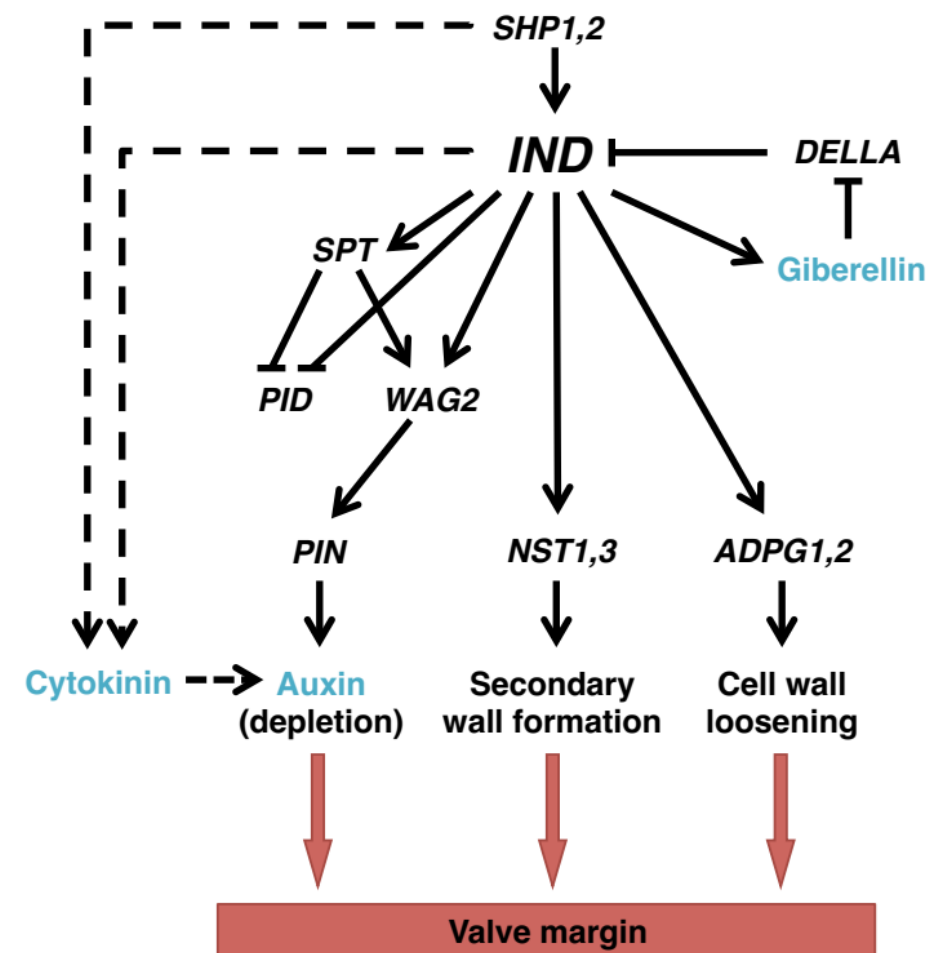

Figure 3. Molecular pathways involved in silique dehiscence in Arabidopsis. (A) Upstream transcription factors regulating dehiscence in Arabidopsis. Green color indicates valve, blue color indicates replum, and red color indicates valve margin identity related genes and processes. Dashed arrow indicates indirect downstream effect. (B) Regulatory pathways downstream of the transcription factor IND (Indehicient). Cyan color indicates hormones involved in shattering. Dashed arrows indicate indirect effect.

Lignification and enzymatic separation of valve margin cells are two necessary processes prior to dehiscence (Figure 2B). NAC secondary wall thickening promoting factor 1 (NST1) and NST3 control secondary wall formation in Arabidopsis siliques [92]. Formation of the secondary wall is 
initiated after the transcription factors FUL, SHP1,2; and IND establishes valve margin and separation layer identities [93]. Polygalacturonases (PGs) are hydrolytic enzymes that play a role in cell wall loosening. Arabidopsis dehiscence zone polygalactuonase1 (ADPG1) and ADPG2 are two PGs required during silique dehiscence in Arabidopsis, and their expression is promoted by IND within the valve margins [94].

Some other crucifers, such as Cardamine hirsute L., have explosive dehiscience, unlike Arabidopsis that has non-explosive shattering [95]. Such explosive shattering is distinct, but likely important for the invasive nature of many weedy crucifers like C. hirsuta or Allaria petiolate, as well as non-crucifers like Impatiens glandulifera Royle. An excellent detailed study shows the lignin deposition in endocarp $b$ cells can generate explosive shattering in C. hirsuta [95]. However, more comparative studies, both within and beyond the Brassicaceae to understand the nature of morphological variation in dehiscience.

\subsection{Shattering in Legumes}

Although transcriptional networks controlling shattering have been well explored in some cereal crops and in Arabidopsis, our knowledge on molecular control of the shattering process in legumes is relatively limited. Genetic analysis of pod shattering has been carried out in various legumes including soybean $[49,95-103]$, common bean $[13,44]$, pea $[18,51,104]$, cowpea $[50,105-108]$, lentil $[16,47,109]$, narrow-leaf lupin [47,108], azuki bean [46,110], and common vetch [44,111]. In most of the legumes that have been studied so far, pod shattering is found to be a dominant trait controlled by one or two genes or QTLs (Table 1). 
Table 1. Pod Shattering QTL in Legumes.

\begin{tabular}{|c|c|c|c|}
\hline Species Name & Identified QTL & Method & Reference \\
\hline Vicia sativa L. (common vetch) & unknown & cross breeding & [44] \\
\hline Vigna angularis (Willd.) Ohwi \& H. Ohashi (azuki bean) & $P d t$ & linkage mapping, QTL analysis & {$[46,110]$} \\
\hline Lupinus angustifolius L. (narrow-leafed lupin) & Lentus, Tardus & linkage mapping, QTL analysis & [112] \\
\hline Lens culinaris Medikus (lentil) & $P i$ & cross breeding, linkage mapping, QTL analysis & {$[16,47,109]$} \\
\hline Vigna unguiculata (L.) Walp. (cowpea) & $D h p / P d d, P d t$ & cross breeding, linkage mapping, QTL analysis & {$[50,105-108]$} \\
\hline Pisum sativum L. (pea) & $D p o 1 / 2, N p / G p$ & linkage mapping, QTL analysis & {$[18,51,104,113]$} \\
\hline Phaseolus vulgaris L. (common bean) & St & linkage mapping, genetic association & {$[13,45,114,115]$} \\
\hline Glycine max L. (soybean) & Pdh1, SHAT1-5 & linkage mapping, QTL analysis, genetic association & {$[49,69,96-103]$} \\
\hline
\end{tabular}


In common vetch, Vicia sativa L., shattering was found to be controlled by a single gene, and recessive mutants were selected during domestication for their non-shattering character [44]. Similar to common vetch, a single gene controls the shattering process in the azuki bean, Vigna angularis $[46,110]$. In narrow-leafed lupin (Lupinus angustifolius L.), two genes are involved in controlling the recessive non-shattering trait [112]. One of the two genes, lentus (le) affects the pod endocarp orientation, reducing the mechanical pressure required for pod shattering, while the second gene tardus (ta) causes the dorsal and ventral pod seams to be fused, inhibiting the separation of the two halves [48].

Over three decades ago, Ladizinsky determined that loss of pod shattering in lentils is regulated by a single Mendelian factor, $\mathrm{Pi}$, while in chickpea shattering is oligogenic [116]. Through the use of crosses between L. culinaris and L. orientalis, pod dehiscence was confirmed to show monogenic inheritance regulated by the Pi locus [47]. A more recent study, however, suggested that pod dehiscence could be a quantitative trait since the segregation ratio for dehiscence and indehiscence was significantly different than 3:1, and intermediate phenotypes were observed in the F2 populations [109]. In chickpea, although Ladizinsky [116] described several loci putatively controlling shattering, Kazan and colleagues described a single recessive gene [117]. This discrepancy could result from different parents being used in different crosses e.g., the widely used CRIL2 recombinant inbred population has been created a few times independently $[117,118]$ and other wild-cultivated crosses have been developed with different parents [119], with post-domestication diversification shifts in modulators of shattering, or differences in dispersal ability among populations of wild Cicer reticulatum. Work utilizing larger numbers of crosses, with distinct wild and cultivated parents and genome-scale genetic maps will be able to clarify the nature of loci involved in shatter in chickpea.

The genetics of pod shattering in cowpea (Vigna unguiculate (L.) Walp.) is not well resolved. While earlier studies found a single gene, Dhp, involved in pod shattering [105], a more recent study showed that the trait may be regulated by a combination of dominant and recessive alleles of several genes [105]. The different results likely stem from different crosses being used in these two studies. Similar to the findings of the more recent study [107], four QTLs concentrated in two regions were shown to regulate pod fiber layer thickness, which control pod shattering in cowpea by two genes $[50,106]$. Pod dehiscence in cowpea may be regulated by a different set of genes. There was no evidence for the involvement of PHD1, IND, or SHP1, major shattering genes in other legumes, as they are not mapped on the major QTLs found to regulate pod dehiscence in cowpea [108].

Pod indehicence in pea, Pisum sativum L., was known to be a monogenic trait controlled by Dpo [104], but since then it was suggested that more genes might be involved in the regulation of this trait [18]. Four QTLs that affect pod dehiscence were identified in pea over time. Other than the previously identified Dpo locus, however, the other QTLs affecting this trait have not been resolved. Potential candidates include the Np locus, which controls undifferentiated tissue (neoplasm) growth, and the Gp locus that controls pod color [51]. The involvement of the Gp locus in pod dehiscence was supported by the observation that yellow pods tend to have thinner walls than green pods, and that pod thickness is an important factor determining the force exerted on the sutures [18]. Genes controlling pod shattering in pea and lentil map to a syntenic region of each genome, suggesting the alleles of same genes may have been favors during the domestication of the two cool-season legumes [18].

Pod indehiscence in common bean, Phaseolus vulgaris, is due to the loss of suture and pod wall fibers that is regulated by the St locus [13]. The P. vulgaris PvIND gene is a homolog of IND (indehiscent), a major silique shattering gene identified in A. thaliana. Since it was mapped near the St locus in common bean, PvIND was predicted to be the pod dehiscence gene underlying the St locus [45]. However, the fact that there were no polymorphisms in PvIND that correlated with the dehiscence/indehiscence phenotype, and that there was not complete co-segregation between PvIND and St suggest PvIND may not be directly involved in pod shattering in common bean [45].

Using recombinant inbred lines and F2 populations, a major QTL controlling pod shattering in soybean was found $[96,97,99,100]$. The major QTLs mapped in these studies all mapped closely to each other, suggesting they are the same locus. This was later identified as a major QTL called 
$q P H D 1$ [49]. In addition to $q P H D 1$, several minor QTLs were identified as regulators of pod shattering in soybean $[95,99,103]$. The gene residing on the qPDH1 locus was not initially identified due to the facts that there were no morphological differences between the wild type and the mutants with shattering resistance associated with $q P D H 1$ locus [99]; that no sequences homologous to the Arabidopsis genes involved in silique dehiscence were found in the region; and that there were six predicted ORFs that showed polymorphisms causing amino acid substitutions [102]. Recently, The PDH1 gene was found to encode a dirigent family protein, and it is expressed in the inner sclerenchyma of pod walls, where a secondary cell wall is formed [98]. PHD1 promotes pod dehiscence via regulating the cell-wall components in inner sclerenchyma either by controlling the primary structure of lignin, or affecting the lignin deposition patterns, and pod shattering resistance was found to be conferred by a loss-of-function of this gene [69]. Another gene conferring pod shattering resistance in soybean was found to be a NAC gene SHAT1-5, which is homologous to the NST1 in A. thaliana. SHAT1-5 controls secondary cell-wall formation by promoting the lignification of fiber cap cells in pod sutures [69].

\section{Crop Losses and the Impact of Environmental Factors on Pod Shattering}

Although pod shattering is a crucial strategy for seed dispersal in wild species $[2,116]$, it has been one of the major limiting factors in improving crop quality and yield in pulse crops when the harvest is delayed and particularly under stressful climatic conditions [120,121]. Swathing (wrapping harvested plants into bundles) prior to complete crop drying combined with the use of desiccant sprays prevents the splitting of the valves upon maturity, and can reduce shattering [122]. However, these techniques rely on determining the precise timing of pod maturity, which can be difficult to assess, as crop development tends to be uneven within and among individuals [123,124]. Applying desiccating agents also increases the costs of crop production. In regions where traditional agricultural practices are preferred, human labor can be the limiting factor for harvest time, potentially causing extensive yield losses $[125,126]$. For these reasons, increasing shatter resistance by selective breeding is favored. However, selecting for shatter resistance is difficult, because several factors other than genetics are involved in shattering including agricultural practices and environmental conditions [127] (Table 2).

Table 2. Factors effecting crop yield due to shattering.

\begin{tabular}{|c|c|c|}
\hline & Species Examined & Reference \\
\hline \multicolumn{3}{|l|}{ Agricultural factors } \\
\hline Harvest method & Brassica napus L. & {$[128,129]$} \\
\hline Harvest time & $\begin{array}{l}\text { Brassica napus L. } \\
\text { Cicer arietinum } \mathrm{L} \text {. } \\
\text { Glycine max } \mathrm{L} \text {. } \\
\text { Lens culinaris Medikus } \\
\text { Triticum aestivum L. }\end{array}$ & $\begin{array}{c}128,129] \\
{[130]} \\
{[131]} \\
{[132]} \\
{[124]}\end{array}$ \\
\hline Seeding time & Brassica napus L. & [129] \\
\hline \multicolumn{3}{|l|}{ Environmental factors } \\
\hline Precipitation & $\begin{array}{l}\text { Brassica napus L. } \\
\text { Glycine max } \mathrm{L} \text {. }\end{array}$ & $\begin{array}{l}{[129]} \\
{[133]}\end{array}$ \\
\hline Wind & Brassica napus L. & [129] \\
\hline Temperature & $\begin{array}{l}\text { Cicer arietinum } \mathrm{L} \text {. } \\
\text { Glycine } \max \mathrm{L} \text {. }\end{array}$ & $\begin{array}{l}{[130]} \\
{[134]}\end{array}$ \\
\hline Humidity & $\begin{array}{l}\text { Brassica napus L. } \\
\text { Glycine } \max \mathrm{L} .\end{array}$ & $\begin{array}{c}{[129,134]} \\
{[133]}\end{array}$ \\
\hline \multicolumn{3}{|l|}{ Structural factors } \\
\hline $\begin{array}{c}\text { Plant architecture } \\
\text { Vascular bundle size } \\
\text { Pod structure } \\
\text { Seed moisture content }\end{array}$ & $\begin{array}{l}\text { Brassica napus } \mathrm{L} . \\
\text { Brassica napus } \mathrm{L} . \\
\text { Brassica napus } \mathrm{L} . \\
\text { Cicer arietinum L. }\end{array}$ & $\begin{array}{l}{[122]} \\
{[135]} \\
{[122]} \\
{[136]}\end{array}$ \\
\hline
\end{tabular}


The effects of agricultural practices on crop yield due to pod shattering are extensively studied in Brassica [137]. In canola, up to 50\% yield loss was reported due to shattering [138], and the degree of yield loss depends on harvesting method and time. The selection of the harvest method is based on crop type and environmental factors. Whereas direct cutting is used to harvest spring crops, swathing is preferred for winter crops, because it minimizes seed loss due to uneven ripening, which is commonly observed in winter crops [128]. Direct cutting is advantageous during rainy and windy seasons, whereas, swathing is preferred in harsh winter conditions, as it protects the crops from frost [129]. Harvest time is also important, as harvesting at the optimum stage of seed development results in higher yield in both winter and spring crops [128,139], and swathing before the crop reaches maturity reduces yield [129]. Delayed harvest was found to have adverse effects on yield in other crops including wheat [124], soybean [131], lentil [132], and chickpea [130]. In addition to harvest time, seeding time also affected crop yield in Brassica, where early seeding gave higher yields [129].

In terms of environmental conditions, yield loss due to shattering can be affected by many factors. In canola, precipitation was the limiting factor in crop yield, and dry conditions were shown to reduce yield [129]. Strong winds can also have negative effects on yield, because it causes canola pods to shatter, further reducing the yield [129]. In soybean, high temperatures and low humidity have been reported to increase yield loss due to pod shattering $[134,140]$. Rapid changes in temperature and humidity were also reported to increase pod shattering in soybean [134], especially when a rainy season was followed by dry weather during harvesting in soybean [133]. Although chickpea is a low-shattering crop, pod shattering could still cause yield loss under high temperatures [130].

In addition to agricultural practices and environmental conditions, structural factors also have an impact on the degree of shattering. In Brassica, taller and sturdier plants tend to produce more shatter-resistance pods [122]. Shatter-resistance in Brassica was also found to be affected by the size and weight of pod structures such as valves, beak, and septum [122,141]. Another study found a positive correlation between shatter-resistance and the main vascular bundle size in Brassica [135]. In chickpea, low seed moisture content, of less than $13 \%$, was also found to cause pod shattering [136].

\section{Efforts to Control Pod Shattering}

Crop improvement is an essential part of the modern agriculture, and developing new techniques and optimizing plant breeding tools are necessary to meet the food demand of a growing human population in drastically changing environments $[139,142-144]$. Early plant breeding efforts were limited to utilizing the advantageous traits via selective breeding, which is a slow process and not a viable option in a rapidly changing environment. The crop improvement process is accelerated via micropropagation, which allows rapid expansion of stock plants, and embryo rescue, which allows crossing of incompatible plants [145]. With the introduction of marker-assisted breeding, traditional methods gained efficiency, but their use is still limited in crops with complex genomes, polyploidy, self-incompatibility, and long generation time [146]. Chemical and radiation-induced mutations can also increase genetic variation, but screening for beneficial mutations while selecting against undesired ones can be time-consuming and expensive [145]. Therefore, even though these methods remain an important part of crop improvement, new techniques are necessary to produce and increase genetic variation in crop species and to increase the efficiency in plant breeding programs.

In order to facilitate the breeding of improved crop varieties, several new techniques have been developed in the last decade. These include agroinfiltration [147], which uses bacterial transformation to induce gene expression, oligonucleotide-directed mutagenesis [148], and zinc-finger nuclease technology [149], both of which allow site-specific gene manipulation; and cisgenesis and intragenesis [150], which involve gene transfer from the same or a cross-compatible species, resulting in plants that can be practically generated using traditional breeding techniques, but in much shorter periods of time [145]. The CRISPR-Cas9 system (Clustered Regularly Interspaced Short Palindromic Repeats/CRISPR Associated Protein 9), and related CRISPR systems, are a set of recently developed 
tools for site-specific genome editing that introduces modifications to the genome at precisely targeted regions, thereby minimizing off-site effects [151].

A general advantage of all these new techniques is that they all save time by speeding up the breeding process due to increased efficiency and specificity. Another advantage of these target-specific methods is that they only introduce the desired gene(s) into the crop, thereby minimizing the contamination of the crop with unwanted genetic material via linkage drag [145]. However, gene editing approaches are still in their infancy, and further improvements are necessary. For instance, despite its high specificity, the CRISPR-Cas9 method may still have potential off-target effects, which could be reduced by increasing the specificity of Cas9, the RNA-guided DNA endonuclease protein, and the guide RNA design, or using alternative endonucleases with higher specificity [152]. One of the steps in gene editing that also needs to be refined is the delivery of the new genetic material. The current transformation methods have low efficiency, and improved delivery methods should be developed [153]. Two other important issues that are largely beyond are scope is the uncertainty regarding the regulatory status of these new methods, and the resistance of many consumers, particularly those in South Asia, to these products. Nevertheless, the products of these new plant breeding techniques can be (i) crops with new genetic material, (ii) crops without new genetic material, but with modified DNA, or (iii) crops without new or modified genetic material [146]. Depending on whether the end products will be classified under genetically modified crops or not, these methods may need extensive regulations and may be met with resistance, which will increase the time cost and alter the market dynamics [145]. Overall, breeding programs would benefit from the development of high-efficiency methods that can be tailored to different genes and crops of interest.

The conventional use of genetic modification tools is to introduce new genetic material into a target organism. However, the same methods can also be used to silence endogenous genes. This is especially important in crop improvement, because many advantageous traits, such as loss of shattering, are often caused by recessive loss-of-function mutations [152]. So far, most of these recent gene editing techniques have focused on disease resistance in crops, but same techniques can be used to improve other traits including shattering-resistance, reduced allergenicity, abiotic stress tolerance, and increased nutritional value [146]. To the best of our knowledge, these techniques have not yet been used to modify any of the known candidate genes for shattering pods.

Several avenues exist to reduce crop losses due to shattering in crops, ranging from traditional selection of parents with lower shattering to screening mutants and gene editing approaches. With the advancement of next-generation sequencing and genome-wide association analysis, several genes involved in pod dehiscence have been discovered, and a variety of mutations underlying shattering resistance have been determined in many crops and their wild relatives [53,154]. In Brassica, efforts to improve shattering resistance include interfering with the dehiscence process via manipulating its molecular and hormonal control pathways [153-156], and generating transgenic lines with pod-shattering resistance [82,83]. For instance, the Arabidopsis gene FUL was successfully transferred to a Brassica crop species, and the ectopic expression of this gene was sufficient to control pod shattering in the Brassica crop [138]. This technique can be applied to other shattering-prone crops. Along with gene editing approaches, future studies should also focus on fine-tuning of the degree of shatter-resistance using RNA interference or using mutated forms of the shattering-related genes in a variety of crops.

\section{Conclusions}

Rapidly growing human population demands increased and sustainable food production in a constantly changing environment. Global challenges such as limited resources and climate change challenge farmers to adopt innovative agriculture practices. Understanding the biodiversity and utilizing the available genetic resources is vital to improve crop production and meet the increasing food demand in the world. 
Shatter resistance is a central trait for many domesticated crops. In the wild, pod dehiscence is a crucial strategy for seed dispersal, but in cultivated crops it is one of the major sources of yield loss during or before harvesting. Therefore, selecting against pod dehiscence was one of the first domestication traits for shattering-prone crops.

A better understanding of this important trait relies on identifying the structures involved in pod shattering, elucidating the molecular and hormonal pathways involved in the dehiscence process, and screening for natural or induced mutations that give rise to shatter-resistance in a variety of crops.

Recent advancements in gene editing technology and further refinements in genome sequencing and molecular marker tools will allow breeders to incorporate shatter resistance to crop breeding programs. Doing so will ultimately increase efficiency in harvesting and minimize yield loss in many crops under a variety of environmental conditions, contributing to food production.

Author Contributions: E.O., A.P., M.K.K., E.M., and E.J.B.v.W. performed the background literature review, R.V.P., A.K., and E.J.B.v.W. framed the question and guided the process, E.O., A.P., M.K.K., and E.J.B.v.W. co-wrote the paper, and all authors contributed to its editing.

Funding: The authors were supported by grants from the US National Science Foundation Plant Genome Program NSF-PGRP 1339346 to E.J.B.v.W. and R.V.P. and by a cooperative agreement from the United States Agency for International Development under the Feed the Future Program AID-OAA-A-14-00008 to E.J.B.v.W., A.K., and R.V.P., E.J.B.v.W.'s work on the domestication of Vigna and the identification of hologous legume shattering genes in Section 4.3 is supported by the Russian Scientific Fund Project No. 18-46-08001.

Acknowledgments: The authors thank Emily Warschefsky, Kassaye Negesh, Bradley Bennett, Andi Kur, Kirstin Bett, and Douglas Cook for helpful discussion.

Conflicts of Interest: The authors declare no conflict of interest.

\section{References}

1. Ballester, P.; Ferrándiz, C. Shattering fruits: Variations on a dehiscent theme. Curr. Opin. Plant Biol. 2017, 35, 68-75. [CrossRef] [PubMed]

2. Howe, H.F.; Smallwood, J. Ecology of seed dispersal. Annu. Rev. Ecol. Syst. 1982, 13, 201-228. [CrossRef]

3. Abbo, S.; Gopher, A. Near Eastern Plant Domestication: A History of Thought. Trends Plant Sci. 2017, 22, 491-511. [CrossRef] [PubMed]

4. Abbo, S.; Van-Oss, R.P.; Gopher, A.; Saranga, Y.; Ofner, I.; Peleg, Z. Plant domestication versus crop evolution: A conceptual framework for cereals and grain legumes. Trends Plant Sci. 2014, 19, 351-360. [CrossRef] [PubMed]

5. Abbo, S.; Saranga, Y.; Peleg, Z.; Kerem, Z.; Lev-Yadun, S.; Gopher, A. Reconsidering domestication of legumes versus cereals in the ancient Near East. Q. Rev. Biol. 2009, 84, 29-50. [CrossRef] [PubMed]

6. Zohary, D. Pulse domestication and cereal domestication: How different are they? Econ. Bot. 1989, 43, 31-34. [CrossRef]

7. Hajjar, R.; Hodgkin, T. The use of wild relatives in crop improvement: A survey of developments over the last 20 years. Euphytica 2007, 156, 1-13. [CrossRef]

8. Brumlop, S.; Reichenbecher, W.; Tappeser, B.; Finckh, M.R. What is the SMARTest way to breed plants and increase agrobiodiversity? Euphytica 2013, 194, 53-66. [CrossRef]

9. Warschefsky, E.; Varma Penmetsa, R.; Cook, D.R.; Von Wettberg, E.J.B. Back to the wilds: Tapping evolutionary adaptations for resilient crops through systematic hybridization with crop wild relatives. Am. J. Bot. 2014, 101, 1791-1800. [CrossRef] [PubMed]

10. Darwin, C. The Variation of Animals and Plants under Domestication; John Murray: London, UK, 1868 ; Volume 8.

11. Vavilov, N.I. The Origin, Variation, Immunity and Breeding of Cultivated Plants; Chester, K.S., Ed.; Chronica Botanica: Waltham, MA, USA, 1951; Volume 72, p. 482.

12. Vavilov, N.I.; Vavylov, M.I.; Dorofeev, V.F. Origin and Geography of Cultivated Plants; Cambridge University Press: Cambridge, UK, 1992.

13. Koinange, E.M.K.; Singh, S.P.; Gepts, P. Genetic control of the domestication syndrome in common bean. Crop Sci. 1996, 36, 1037-1045. [CrossRef]

14. Konishi, S.; Izawa, T.; Lin, S.Y.; Ebana, K.; Fukuta, Y.; Sasaki, T.; Yano, M. An SNP caused loss of seed shattering during rice domestication. Science 2006, 312, 1392-1396. [CrossRef] [PubMed] 
15. Li, N.; Zhang, D.S.; Liu, H.S.; Yin, C.S.; Li, X.; Liang, W.; Yuan, Z.; Xu, B.; Chu, H.W.; Wang, J.; et al. The rice tapetum degeneration retardation gene is required for tapetum degradation and anther development. Plant Cell 2006, 18, 2999-3014. [CrossRef] [PubMed]

16. Ladizinsky, G. The genetics of several morphological traits in the lentil. J. Hered. 1979, 70, 135-137. [CrossRef]

17. Simons, K.J.; Fellers, J.P.; Zhang, Z.C.; Faris, J.D. Molecular Characterization of the Major Wheat Domestication Gene Q. Genetics 2006, 172, 547-555. [CrossRef] [PubMed]

18. Weeden, N.F.; Brauner, S.; Przyborowski, J.A. Genetic Analysis of Pod Dehiscence in Pea (Pisum Sativum L.). Cell. Mol. Biol. Lett. 2002, 7, 657-663. [PubMed]

19. Lin, Z.; Li, X.; Shannon, L.; Yeh, C.; Wang, M.; Bai, G.; Peng, Z.; Li, J.; Trick, H.; Clemente, T.; et al. Parallel domestication of the Shattering1 genes in cereals. Nat. Genet. 2012, 44, 720-724. [CrossRef] [PubMed]

20. Paterson, A.H.; Lin, Y.R.; Li, Z.; Schertz, K.F.; Doebley, J.F.; Pinson, S.R.M.; Liu, S.C.; Stansel, J.W.; Irvine, J.E. Convergent domestication of cereal crops by independent mutations at corresponding genetic loci. Science 1995, 269, 1714-1718. [CrossRef] [PubMed]

21. Lewis, G.P. Legumes of the World; Royal Botanic Gardens Kew: London, UK, 2005.

22. Azani, N.; Babineau, M.; Bailey, C.D.; Banks, H.; Barbosa, A.R.; Pinto, R.B.; Boatwright, J.S.; Borges, L.M.; Brown, G.K.; Bruneau, A.; et al. A new subfamily classification of the Leguminosae based on a taxonomically comprehensive phylogeny-The Legume Phylogeny Working Group (LPWG). Taxon 2017, 66, 44-77. [CrossRef]

23. Foyer, C.H.; Lam, H.M.; Nguyen, H.T.; Siddique, K.H.M.; Varshney, R.K.; Colmer, T.D.; Cowling, W.; Bramley, H.; Mori, T.A.; Hodgson, J.M.; et al. Neglecting legumes has compromised human health and sustainable food production. Nat. Plants 2016, 2, 16112. [CrossRef] [PubMed]

24. Considine, M.J.; Siddique, K.H.M.; Foyer, C.H. Nature's pulse power: Legumes, food security and climate change. J. Exp. Bot. 2017, 68, 1815-1818. [CrossRef] [PubMed]

25. Adams, M.A.; Buchmann, N.; Sprent, J.; Buckley, T.N.; Turnbull, T.L. Crops, Nitrogen, Water: Are Legumes Friend, Foe, or Misunderstood Ally? Trends Plant Sci. 2018, 23, 539-550. [CrossRef] [PubMed]

26. Fuller, D.Q.; Harvey, E.L. The archaeobotany of Indian pulses: Identification, processing and evidence for cultivation. Environ. Archaeol. 2006, 11, 219-246. [CrossRef]

27. Krieg, C.P.; Kassa, M.T.; von Wettberg, E.J.B. Germplasm Characterization and Trait Discovery. In The Pigeonpea Genome; Springer: Basel, Switzerland, 2017; pp. 65-79.

28. Prosperi, J.M.; Jenczewski, E.; Muller, M.H.; Fourtier, S.; Sampoux, J.P.; Ronfort, J. Alfalfa domestication history, genetic diversity and genetic resources. Legume Perspectives 2014, 4, 13-14.

29. Gladstones, J.S. (Ed.) Lupins as crop plants. Field Crop abstr. 1970, 23, 123-148.

30. Caracuta, V.; Barzilai, O.; Khalaily, H.; Milevski, I.; Paz, Y.; Vardi, J.; Regev, L.; Boaretto, E. The onset of faba bean farming in the Southern Levant. Sci. Rep. 2015, 5, 14370. [CrossRef] [PubMed]

31. Caracuta, V.; Vardi, J.; Paz, Y.; Boaretto, E. Farming legumes in the pre-pottery Neolithic: New discoveries from the site of Ahihud (Israel). PLoS ONE 2017, 12, e0177859. [CrossRef] [PubMed]

32. Fuller, D.Q.; Denham, T.; Arroyo-Kalin, M.; Lucas, L.; Stevens, C.J.; Qin, L.; Allaby, R.G.; Purugganan, M.D. Convergent evolution and parallelism in plant domestication revealed by an expanding archaeological record. Proc. Natl. Acad. Sci. USA 2014, 111, 6147-6152. [CrossRef] [PubMed]

33. Purugganan, M.D.; Fuller, D.Q. The Nature of Selection During Plant Domestication. Nature 2009, 457, 843-848. Available online: https:/ / www.nature.com/articles/nature07895 (accessed on 2 June 2018).

34. Meyer, R.S.; Purugganan, M.D. Evolution of crop species: genetics of domestication and diversification. Nat. Rev. Genet. 2013, 14, 840-852. [CrossRef] [PubMed]

35. Doebley, J.F.; Gaut, B.S.; Smith, B.D. The molecular genetics of crop domestication. Cell 2006, 127, $1309-1321$. [CrossRef] [PubMed]

36. Bitocchi, E.; Bellucci, E.; Giardini, A.; Rau, D.; Rodriguez, M.; Biagetti, E.; Santilocchi, R.; Zeuli, P.S.; Gioia, T.; Logozzo, G.; et al. Molecular analysis of the parallel domestication of the common bean (Phaseolus vulgaris) in Mesoamerica and the Andes. New Phytol. 2013, 197, 300-313. [CrossRef] [PubMed]

37. Schmutz, J.; McClean, P.E.; Mamidi, S.; Wu, G.A.; Cannon, S.B.; Grimwood, J.; Jenkins, J.; Shu, S.; Song, Q.; Chavarro, C.; et al. A reference genome for common bean and genome-wide analysis of dual domestications. Nat. Genet. 2014, 46, 707-713. [CrossRef] [PubMed]

38. Hammer, K. Das Domestikationssyndrom. Die Kult. 1984, 32, 11-34. [CrossRef] 
39. Vaughan, D.A.; Balázs, E.; Harrison, J.S.H. From Crop Domestication to Super-Domestication. Ann. Bot. 2007, 100, 893-901. [CrossRef] [PubMed]

40. Fuller, D.Q. Contrasting patterns in crop domestication and domestication rates: Recent archaeobotanical insights from the Old World. Ann. Bot. 2007, 100, 903-924. [CrossRef] [PubMed]

41. Fernández-Martin, B.; Milla, R.; Martin-Robles, N.; Arc, E.; Kranner, I.; Becerril, J.M.; Garcia-Plazaola, J.I. Side-effects of domestication: Cultivated legume seeds contain similar tocopherols and fatty acids but less carotenoids than their wild counterparts. BMC Plant Biol. 2014, 14, 1599. [CrossRef]

42. Kerem, Z.; Lev-Yadun, S.; Gopher, A.; Weinberg, P.; Abbo, S. Chickpea domestication in the Neolithic Levant through the nutritional perspective. J. Archaeol. Sci. 2007, 34, 1289-1293. [CrossRef]

43. Zohary, D. Unconscious selection and the evolution of domesticated plants. Econ. Bot. 2004, 58, 5-10. [CrossRef]

44. Abd El-Moneim, A.M. Selection for Non-Shattering Common Vetch, Vicia sativa L. Plant Breed. 1993, 110, 168-171. [CrossRef]

45. Gioia, T.; Logozzo, G.; Kami, J.; Spagnoletti Zeuli, P.; Gepts, P. Identification and characterization of a homologue to the Arabidopsis INDEHISCENT gene in common bean. J. Hered. 2012, 104, 273-286. [CrossRef] [PubMed]

46. Kaga, A.; Isemura, T.; Tomooka, N.; Vaughan, D.A. The genetics of domestication of the azuki bean (Vigna angularis). Genetics 2008, 178, 1013-1036. [CrossRef] [PubMed]

47. Tahir, M.; Muehlbauer, F.J. Gene mapping in Lentil with Recombinant Inbred Lines. J. Hered. 1994, 85, 306-310. [CrossRef]

48. Boersma, J.G.; Nelson, M.N.; Sivasithamparam, K.; Yang, H. Development of sequence-specific PCR markers linked to the Tardus gene that reduces pod shattering in narrow-leafed lupin (Lupinus angustifolius L.). Mol. Breed 2009, 23, 259-267. [CrossRef]

49. Funatsuki, H.; Hajika, M.; Hagihara, S.; Yamada, T.; Tanaka, Y.; Tsuji, H.; Ishimoto, M.; Fujino, K. Confirmation of the location and the effects of a major QTL controlling pod dehiscence, qPDH1, in soybean. Breed. Sci. 2008, 58, 63-69. [CrossRef]

50. Kongjaimun, A.; Kaga, A.; Tomooka, N.; Somta, P.; Vaughan, D.A.; Srinives, P. The genetics of domestication of yardlong bean, Vigna unguiculata (L.) Walp. ssp. unguiculata cv.-gr. sesquipedalis. Ann. Bot. 2012, 109, 1185-1200. [CrossRef] [PubMed]

51. Weeden, N.F. Genetic changes accompanying the domestication of Pisum sativum: Is there a common genetic basis to the domestication syndrome for legumes? Ann. Bot. 2007, 100, 1017-1025. [CrossRef] [PubMed]

52. Lewis, M.W.; Leslie, M.E.; Liljegren, S.J. Plant separation: 50 ways to leave your mother. Curr. Opin. Plant Biol. 2006, 9, 59-65. [CrossRef] [PubMed]

53. Dong, Y.; Wang, Y.Z. Seed shattering: From models to crops. Front. Plant Sci. 2015, 6, 476. [CrossRef] [PubMed]

54. Hu, Z.; Yang, H.; Zhang, L.; Wang, X.; Liu, G.; Wang, H.; Hua, W. A large replum-valve joint area is associated with increased resistance to pod shattering in rapeseed. J. Plant Res. 2015, 128, 813-819. [CrossRef] [PubMed]

55. Lenser, T.; Theißen, G. Molecular mechanisms involved in convergent crop domestication. Trends Plant Sci. 2013, 18, 704-714. [CrossRef] [PubMed]

56. Dardick, C.; Callahan, A.M. Evolution of the fruit endocarp: Molecular mechanisms underlying adaptations in seed protection and dispersal strategies. Front. Plant Sci. 2014, 5, 284. [CrossRef] [PubMed]

57. Østergaard, L.; Borkhardt, B.; Ulvskov, P. Dehiscence. In Annual Plant Reviews; Roberts, J.A., Gonzalez-Carranza, Z., Eds.; John Wiley \& Sons: Chichester, UK, 2007; Volume 25, pp. 137-163.

58. Ferrándiz, C.; Pelaz, S.; Yanofsky, M.F. Control of carpel and fruit development in Arabidopsis. Annu. Rev. Biochem. 1999, 68, 321-354. [CrossRef] [PubMed]

59. Roberts, J.A.; Elliott, K.A.; Gonzalez-Carranza, Z.H. Abscission, dehiscence, and other cell separation processes. Annu. Rev. Plant Biol. 2002, 53, 131-158. [CrossRef] [PubMed]

60. Meakin, P.J.; Roberts, J.A. Dehiscence of fruit in oilseed rape (Brassica napus L.) II. The role of cell wall degrading enzymes and ethylene. J. Exp. Bot. 1990, 41, 1003-1011. [CrossRef]

61. Meakin, P.J.; Roberts, J.A. Dehiscence of fruit in oilseed rape (Brassica napus L.) I. Anatomy of pod dehiscence. J. Exp. Bot. 1990, 41, 955-1002. [CrossRef]

62. Morgan, C.L.; Bruce, D.M.; Child, R.; Ladbrooke, Z.L.; Arthur, A.E. Genetic variation for pod shatter resistance among lines of oilseed rape developed from synthetic B. napus. Field. Crop. Res. 1998, 58, $153-165$. [CrossRef] 
63. Sorefan, K.; Girin, T.; Liljegren, S.; Ljung, K.; Robles, P.; Galvin-Ampudia, C.; Offringa, R.; Friml, J.; Yanofsky, M.F.; Ostergaard, L. A regulated auxin minimum is required for seed dispersal. Nature 2009, 459, 583-586. [CrossRef] [PubMed]

64. Chauvaux, N.; Child, R.; John, K.; Ulvskov, P.; Borkhardt, B.; Prinsen, E.; Van Onckelen, H.A. The role of auxin in cell separation in the dehiscence zone of oilseed rape pods. J. Exp. Bot. 1997, 48, 1423-1429. [CrossRef]

65. Marsch-Martínez, N.; Ramos-Cruz, D.; Irepan Reyes-Olalde, J.; Lozano-Sotomayor, P.; Zúñiga-Mayo, V.M.; De Folter, S. The role of cytokinin during Arabidopsis gynoecia and fruit morphogenesis and patterning. Plant J. 2012, 72, 222-234. [CrossRef] [PubMed]

66. Christiansen, L.C.; Dal Degan, F.; Ulvskov, P.; Borkhardt, B. Examination of the dehiscence zone in soybean pods and isolation of a dehiscence-related endopolygalacturonase gene. Plant Cell Environ. 2002, 25, 479-490. [CrossRef]

67. Zhang, Y.; Shen, Y.Y.; Wu, X.M.; Wang, J.B. The basis of pod dehiscence: Anatomical traits of the dehiscence zone and expression of eight pod shatter-related genes in four species of Brassicaceae. Biol. Plant. 2016, 60, 343-354. [CrossRef]

68. Tiwari, S.; Bhatia, V. Characters of pod anatomy associated with pod shatering in soybean. Ann. Bot. 1995, 76, 483-485. [CrossRef]

69. Dong, Y.; Yang, X.; Liu, J.; Wang, B.H.; Liu, B.L.; Wang, Y.Z. Pod shattering resistance associated with domestication is mediated by a NAC gene in soybean. Nat. Commun. 2014, 5, 3352. [CrossRef] [PubMed]

70. Glémin, S.; Bataillon, T. A comparative view of the evolution of grasses under domestication. New Phytol. 2009, 183, 273-290. [CrossRef] [PubMed]

71. Sang, T. Genes and Mutations Underlying Domestication Transitions in Grasses. Plant Physiol. 2009, 149, 63-70. [CrossRef] [PubMed]

72. Li, L.; Olsen, K.M. Chapter Three-To Have and to Hold: Selection for Seed and Fruit Retention During Crop Domestication. Curr. Top. Dev. Biol. 2016, 119, 63-109. [CrossRef] [PubMed]

73. Li, W.; Gill, B.S. Multiple genetic pathways for seed shattering in the grasses. Funct. Integr. Genom. 2006, 6, 300-309. [CrossRef] [PubMed]

74. Estornell, L.H.; Agusti, J.; Merelo, P.; Talón, M.; Tadeo, F.R. Elucidating mechanisms underlying organ abscission. Plant Sci. 2013, 199, 48-60. [CrossRef] [PubMed]

75. Zhou, Y.; Lu, D.; Li, C.; Luo, J.; Zhu, B.; Zhu, J.; Shangguan, Y.; Wang, Z.; Sang, T.; Zhou, B.; et al. Genetic Control of Seed Shattering in Rice by the APETALA2 Transcription Factor SHATTERING ABORTION1. Plant Cell 2012, 24, 1034-1048. [CrossRef] [PubMed]

76. Yoon, J.; Cho, L.H.; Kim, S.L.; Choi, H.; Koh, H.J.; An, G. The BEL1-type homeobox gene SH5 induces seed shattering by enhancing abscission-zone development and inhibiting lignin biosynthesis. Plant J. 2014, 79, 717-728. [CrossRef] [PubMed]

77. Faris, J.D.; Fellers, J.P.; Brooks, S.A.; Gill, B.S. A bacterial artificial chromosome contig spanning the major domestication locus $Q$ in wheat and identification of a candidate gene. Genetics 2003, 164, 311-321. [PubMed]

78. Kato, K.; Miura, H.; Sawada, S. QTL mapping of genes controlling ear emergence time and plant height on chromosome 5A of wheat. Theor. Appl. Genet. 1999, 98, 472-477. [CrossRef]

79. Muramatsu, M. Dosage effect of the spelta gene q of hexaploid wheat. Genetics 1963, 48, 469-482. [PubMed]

80. Tang, H.; Cuevas, H.E.; Das, S.; Sezen, U.U.; Zhou, C.; Guo, H.; Goff, V.H.; Ge, Z.; Clemente, T.E.; Paterson, A.H. Seed shattering in a wild sorghum is conferred by a locus unrelated to domestication. Proc. Natl. Acad. Sci. USA 2013, 110, 15824-15829. [CrossRef] [PubMed]

81. Arnaud, N.; Girin, T.; Sorefan, K.; Fuentes, S.; Wood, T.A.; Lawrenson, T.; Sablowski, R.; Østergaard, L. Gibberellins control fruit patterning in Arabidopsis thaliana. Genes Dev. 2010, 24, 2127-2132. [CrossRef] [PubMed]

82. Liljegren, S.; Ditta, G.; Eshed, Y.; Savidge, B. SHATTERPROOF MADS-box genes control seed dispersal in Arabidopsis. Nature 2000, 404, 766-770. [CrossRef] [PubMed]

83. Liljegren, S.J.; Roeder, A.H.K.; Kempin, S.A.; Gremski, K.; Østergaard, L.; Guimil, S.; Reyes, D.K.; Yanofsky, M.F. Control of fruit patterning in Arabidopsis by INDEHISCENT. Cell 2004, 116, 843-853. [CrossRef]

84. Rajani, S.; Sundaresan, V. The Arabidopsis myc/bHLH gene alcatraz enables cell separation in fruit dehiscence. Curr. Biol. 2001, 11, 1914-1922. [CrossRef] 
85. Roeder, A.H.K.; Ferrándiz, C.; Yanofsky, M.F. The role of the REPLUMLESS homeodomain protein in patterning the Arabidopsis fruit. Curr. Biol. 2003, 13, 1630-1635. [CrossRef] [PubMed]

86. Gu, Q.; Ferrándiz, C.; Yanofsky, M.F.; Martienssen, R. The FRUITFULL MADS-box gene mediates cell differentiation during Arabidopsis fruit development. Development 1998, 125, 1509-1517. [PubMed]

87. Dinneny, J.R.; Weigel, D.; Yanofsky, M.F. A genetic framework for fruit patterning in Arabidopsis thaliana. Development 2005, 132, 4687-4696. [CrossRef] [PubMed]

88. Savidge, B. Temporal Relationship between the Transcription of Two Arabidopsis MADS Box Genes and the Floral Organ Identity Genes. Plant Cell 1995, 7, 721-733. [CrossRef] [PubMed]

89. Ripoll, J.J.; Roeder, A.H.K.; Ditta, G.S.; Yanofsky, M.F. A novel role for the floral homeotic gene APETALA2 during Arabidopsis fruit development. Development 2011, 138, 5167-5176. [CrossRef] [PubMed]

90. Petrášek, J.; Mravec, J.; Bouchard, R.; Blakeslee, J.; Abas, M.; Seifertova, D.; Wisnieska, J.; Tadele, Z.; Kubes, M.; Covanova, M.; et al. PIN proteins perform a rate-limiting function in cellular auxin efflux. Science 2006, 312, 914-918. [CrossRef] [PubMed]

91. Girin, T.; Paicu, T.; Stephenson, P.; Fuentes, S.; Körner, E.; O’Brien, M.; Sorefan, K.; Wood, T.A.; Balanzá, V.; Ferrándiz, C.; et al. INDEHISCENT and SPATULA interact to specify carpel and valve margin tissue and thus promote seed dispersal in Arabidopsis. Plant Cell 2011, 23, 3641-3653. [CrossRef] [PubMed]

92. Zhong, R.; Demura, T.; Ye, Z.H. SND1, a NAC Domain Transcription Factor, Is a Key Regulator of Secondary Wall Synthesis in Fibers of Arabidopsis. Plant Cell 2006, 18, 3158-3170. [CrossRef] [PubMed]

93. Mitsuda, N.; Ohme-Takagi, M. NAC transcription factors NST1 and NST3 regulate pod shattering in a partially redundant manner by promoting secondary wall formation after the establishment of tissue identity. Plant J. 2008, 56, 768-778. [CrossRef] [PubMed]

94. Ogawa, M.; Kay, P.; Wilson, S.; Swain, S.M. ARABIDOPSIS DEHISCENCE ZONE POLYGALACTURONASE1 (ADPG1), ADPG2, and QUARTET2 Are Polygalacturonases Required for Cell Separation during Reproductive Development in Arabidopsis. Plant Cell 2009, 21, 216-233. [CrossRef] [PubMed]

95. Hofhuis, H.; Moulton, D.; Lessinnes, T.; Routier-Kierzkowska, A.L.; Bomphrey, R.J.; Mosca, G.; Reinhardt, H.; Sarchet, P.; Gan, X.; Tsiantis, M.; et al. Morphomechanical innovation drives explosive seed dispersal. Cell 2016, 166, 222-233. [CrossRef] [PubMed]

96. Bailey, M.A.; Mian, M.A.R.; Carter, T.E., Jr.; Ashley, D.A.; Boerma, H.R. Pod dehiscence of soybean: Identification of quantitative trait loci. J. Hered. 1997, 88, 152-154. [CrossRef]

97. Funatsuki, H.; Ishimoto, M.; Tsuji, H.; Kawaguchi, K.; Hajika, M.; Fujino, K. Simple sequence repeat markers linked to a major QTL controlling pod shattering in soybean. Plant Breed 2006, 125, 195-197. [CrossRef]

98. Funatsuki, H.; Suzuki, M.; Hirose, A.; Inaba, H.; Yamada, T.; Hajika, M.; Komatsu, K.; Katayama, T.; Sayama, T.; Ishimoto, M.; et al. Molecular basis of a shattering resistance boosting global dissemination of soybean. Proc. Natl. Acad. Sci. USA 2014, 111, 17797-17802. [CrossRef] [PubMed]

99. Kang, S.T.; Kwak, M.; Kim, H.K.; Choung, M.G.; Han, W.Y.; Baek, I.Y.; Kim, M.Y.; Van, K.; Lee, S.H. Population-specific QTLs and their different epistatic interactions for pod dehiscence in soybean [Glycine max (L.) Merr.]. Euphytica 2009, 166, 15. [CrossRef]

100. Liu, B.; Fujita, T.; Yan, Z.; Sakamoto, S.; Xu, D.; Abe, J. QTL Mapping of Domestication-related Traits in Soybean (Glycine max). Ann. Bot. 2007, 100, 1027-1038. [CrossRef] [PubMed]

101. Suzuki, M.; Fujino, K.; Funatsuki, H.A. Major Soybean QTL, qPDH1, Controls Pod Dehiscence without Marked Morphological Change. Plant Prod. Sci. 2009, 12, 217-223. [CrossRef]

102. Suzuki, M.; Fujino, K.; Nakamoto, Y.; Ishimoto, M.; Funatsuki, H. Fine mapping and development of DNA markers for the qPDH1 locus associated with pod dehiscence in soybean. Mol. Breed. 2010, 25, 407-418. [CrossRef]

103. Yamada, T.; Funatsuki, H.; Hagihara, S.; Fujita, S.; Tanaka, Y.; Tsuji, H.; Ishimoto, M.; Fujino, K.; Hajika, M.A. major QTL, qPDH1, is commonly involved in shattering resistance of soybean cultivars. Breed. Sci. 2009, 59, 435-440. [CrossRef]

104. Blixt, S. Mutation genetics in Pisum. In Agri Hortique Genetica; Food and Agriculture Organization of the United Nations: Rome, Italy, 1972; p. 30.

105. Aliboh, V.O.; Kehinde, O.B.; Fawole, I. Inheritance of leaf mark, pod dehiscence and dry pod colour in crosses between wild and cultivated cowpeas. Afr. Crop Sci. J. 1996, 4, 283-288. 
106. Andargie, M.; Pasquet, R.S.; Gowda, B.S.; Muluvi, G.M.; Timko, M.P. Construction of a SSR-based genetic map and identification of QTL for domestication traits using recombinant inbred lines from a cross between wild and cultivated cowpea (V. unguiculata (L.) Walp.). Mol. Breed. 2011, 28, 413-420. [CrossRef]

107. Mohammed, M.S.; Russom, Z.; Abdul, S.D. Inheritance of hairiness and pod shattering, heritability and correlation studies in crosses between cultivated cowpea (Vigna unguiculata (L.) Walp.) and its wild (var. pubescens) relative. Euphytica 2009, 171, 397-407. [CrossRef]

108. Suanum, W.; Somta, P.; Kongjaimun, A.; Yimram, T.; Kaga, A.; Tomooka, N.; Takahashi, Y.; Srinives, P. Co-localization of QTLs for pod fiber content and pod shattering in F2 and backcross populations between yardlong bean and wild cowpea. Mol. Breed 2016, 36, 80. [CrossRef]

109. Fratini, R.; Durán, Y.; Garcia, P.; De La Vega, M.P. Identification of quantitative trait loci (QTL) for plant structure, growth habit and yield in lentil. Spanish J. Agric. Res. 2007, 5, 348-356. [CrossRef]

110. Isemura, T.; Kaga, A.; Konishi, S.; Ando, T.; Tomooka, N.; Han, O.K.; Vaughan, D.A. Genome dissection of traits related to domestication in azuki bean (Vigna angularis) and comparison with other warm-season legumes. Ann. Bot. 2007, 100, 1053-1071. [CrossRef] [PubMed]

111. Dong, R.; Dong, D.; Luo, D.; Zhou, Q.; Chai, X.; Zhang, J.; Xie, W.; Liu, W.; Dong, Y.; Wang, Y.; et al. Transcriptome Analyses Reveal Candidate Pod Shattering-Associated Genes Involved in the Pod Ventral Sutures of Common Vetch (Vicia sativa L.). Front. Plant Sci. 2017, 8, 649. [CrossRef] [PubMed]

112. Nelson, M.N.; Phan, H.T.T.; Ellwood, S.R.; Moolhuijzen, P.M.; Hane, J.; Williams, A.; O'Lone, C.E.; Fosu-Nyarko, J.; Scobie, M.; Cakir, M.; et al. The first gene-based map of Lupinus angustifolius L.-location of domestication genes and conserved synteny with Medicago truncatula. Theor. Appl. Genet. 2006, 113, 225-238. [CrossRef] [PubMed]

113. Hradilová, I.; Trněný, O.; Válková, M.; Cechová, M.; Janská, A.; Prokešová, L.; Aamir, K.; Krezdorn, N.; Rotter, B.; Winter, P.; et al. A combined comparative transcriptomic, metabolomic, and anatomical analyses of two key domestication traits: Pod dehiscence and seed dormancy in pea (Pisum sp.). Front. Plant Sci. 2017, 8, 542. [CrossRef] [PubMed]

114. Hagerty, C.H.; Cuesta-Marcos, A.; Cregan, P.; Song, Q.; McClean, P.; Myers, J.R. Mapping snap bean pod and color traits, in a dry bean $\times$ snap bean recombinant inbred population. J. Am. Soc. Hortic. Sci. 2016, 141, 131-138.

115. Nanni, L.; Bitocchi, E.; Bellucci, E.; Rossi, M.; Rau, D.; Attene, G.; Gepts, P.; Papa, R. Nucleotide diversity of a genomic sequence similar to SHATTERPROOF (PvSHP1) in domesticated and wild common bean (Phaseolus vulgaris L.). Theor. Appl. Genet. 2011, 123, 1341-1357. [CrossRef] [PubMed]

116. Ladizinsky, G. Seed dispersal in relation to the domestication of Middle East legumes. Econ. Bot. 1979, 33, 284-289. [CrossRef]

117. Kazan, K.; Muehlbauer, F.J.; Weeden, N.E.; Ladizinsky, G. Inheritance and linkage relationships of morphological and isozyme loci in chickpea (Cicer arietinum L.). Theor. Appl. Genet. 1993, 86, 417-426. [CrossRef] [PubMed]

118. Gaur, P.M.; Slinkard, A.E. Genetic control and linkage relations of additional isozyme markers in chick-pea. Theor. Appl. Genet. 1990, 80, 648-656. [CrossRef] [PubMed]

119. Von Wettberg, E.J.B.; Chang, P.L.; Başdemir, F.; Carrasquila-Garcia, N.; Korbu, L.B.; Moenga, S.M.; Bedada, G.; Greenlon, A.; Moriuchi, K.S.; Singh, V.; et al. Ecology and genomics of an important crop wild relative as a prelude to agricultural innovation. Nat. Commun. 2018, 9. [CrossRef] [PubMed]

120. Gan, Y.; Blackshaw, R.E.; May, W.E.; Vera, C.; Johnson, E.N. Yield Stability and Seed Shattering Characteristics of Brassica juncea Canola in the Northern Great Plains. Crop Sci. 2016, 56, 1296-1305. [CrossRef]

121. Cavalieri, A.; Lewis, D.W.; Gulden, R.H. Pod drop and pod shatter are not closely related in canola. Crop Sci. 2014, 54, 1184-1188. [CrossRef]

122. Summers, J.E.; Bruce, D.M.; Vancanneyt, G.; Redig, P.; Werner, C.P.; Morgan, C.; Child, R.D. Pod shatter resistance in the resynthesized Brassica napus line DK142. J. Agric. Sci. 2003, 140, 43-52. [CrossRef]

123. Baloch, U.K. Wheat: Post-harvest operations; Food and Agriculture Organization of the United Nations: Rome, Italy, 1999.

124. Grover, D.K.; Singh, J.M. Post-harvest Losses in Wheat Crop in Punjab: Past and Present. Agric. Econ. Res. Rev. 2013, 26, 293-297.

125. Tukamuhabwa, P.; Dashiell, K.; Rubaihayo, P.; Nanasirye, M. Determination of field yield loss and effect of environment on pod shattering in soybean. Afr. Crop Sci. J. 2002, 10, 203-209. 
126. Zhang, L.; Boahen, S. Evaluation of critical shattering time of early-maturity soybeans under early soybean production system. Agric. Biol. J. 2010, 1, 440-447. [CrossRef]

127. Gan, Y.; Malhi, S.S.; Brandt, S.A.; McDonald, C.L. Assessment of seed shattering resistance and yield loss in five oilseed crops. Can. J. Plant Sci. 2008, 88, 267-270. [CrossRef]

128. Price, J.S.; Hobson, R.N.; Neale, M.A.; Bruce, D.M. Seed losses in commercial harvesting of oilseed rape. J. Agric. Eng. Res. 1996, 65, 183-191. [CrossRef]

129. Vera, C.L.; Downey, R.K.; Woods, S.M.; Raney, J.P.; McGregor, D.I.; Elliott, R.H.; Johnson, E.N. Yield and quality of canola seed as affected by stage of maturity at swathing. Can. J. Plant Sci. 2007, 87, 13-26. [CrossRef]

130. Van Gastel, A.; Bishaw, Z.; Niane, A.; Gregg, B.; Gan, Y. Chickpea seed production. In Chickpea Breeding and Management; Yadav, S.S., Chen, W., Eds.; CABI (Centre for Agriculture and Bioscience International) International: Oxford, UK, 2007; pp. 417-444.

131. Philbrook, B.D.; Oplinger, E.S. Soybean Field Losses as Influenced by Harvest Delays. Agron. J. 1989, 81, 251-258. [CrossRef]

132. Erskine, W. Selection for pod retention and pod indehiscence in lentils. Euphytica 1985, 34, 105-112. [CrossRef]

133. Tiwari, S.; Bhatnager, P. Minimizing pod shattering in soybean. In India Farming; ICAR: Indore, India, 1989; Volume 39, pp. 23-24.

134. Tsuchiya, T. Physiological and Genetic Analysis of Pod Shattering in Soybeans. Jpn. Agric. Res. Q. 1987, 21, 166-175.

135. Child, R.D.; Summers, J.E.; Babij, J.; Farrent, J.W.; Bruce, D.M. Increased resistance to pod shatter is associated with changes in the vascular structure in pods of a resynthesized Brassica napus line. J. Exp. Bot. 2003, 54, 1919-1930. [CrossRef] [PubMed]

136. Margheim, J.F.; Baltensperger, D.D.; Wilson, R.G.; Lyon, D.J.; Hein, G.L.; Harveson, R.M.; Burgener, P.A.; Krall, J.M.; Cecil, J.T.; Rickertsen, J.R.; et al. Chickpea Production in the High Plains; University of Nebraska-Lincoln: Lincoln, NE, USA, 2004.

137. Gulden, R.H.; Cavalieri, A.; Syrovy, L.D.; Shirtliffe, S.J. Pod drop in Brassica napus is linked to weight-adjusted pod-retention resistance. Field. Crop. Res. 2017, 205, 34-44. [CrossRef]

138. Østergaard, L.; Kempin, S.A.; Bies, D.; Klee, H.J.; Yanofsky, M.F. Pod shatter-resistant Brassica fruit produced by ectopic expression of the FRUITFULL gene. Plant Biotechnol. J. 2006, 4, 45-51. [CrossRef] [PubMed]

139. Sintim, H.; Zheljazkov, V.; Obour, A.K. Managing harvest time to control pod shattering in oilseed camelina. Agon. J. 2016, 108, 656-661. [CrossRef]

140. Li, X.R.; Deb, J.; Kumar, S.V.; Østergaard, L. Temperature Modulates Tissue-Specification Program to Control Fruit Dehiscence in Brassicaceae. Mol. Plant 2018, 11, 598-606. [CrossRef] [PubMed]

141. Kuai, J.; Sun, Y.; Liu, T.; Zhang, P.; Zhou, M.; Wu, J.; Zhou, G. Physiological mechanisms behind differences in pod shattering resistance in rapeseed (Brassica napus L.) varieties. PLoS ONE 2016, 11, e0157341. [CrossRef] [PubMed]

142. Liu, C.; Gan, Y.; Poppy, L. Evaluation of on-farm crop management decisions on canola productivity. Can. J. Plant Sci. 2014, 94, 131-139. [CrossRef]

143. Alberti, P.K. Development of Best Management Practices for Production of Ethiopian Mustard (Brassica carinata) in South Dakota. Master's Thesis, South Dakota State University, Brookings, SD, USA, 18 December 2017.

144. Kumar, D.; Kalita, P. Reducing postharvest losses during storage of grain crops to strengthen food security in developing countries. Foods 2017, 6, 8. [CrossRef] [PubMed]

145. Lusser, M.; Parisi, C.; Plan, D.; Rodríguez-Cerezo, E. Deployment of new biotechnologies in plant breeding. Nat. Biotechnol. 2012, 30, 231-239. [CrossRef] [PubMed]

146. Schaart, J.G.; van de Wiel, C.C.M.; Lotz, L.A.P.; Smulders, M.J.M. Opportunities for Products of New Plant Breeding Techniques. Trends Plant Sci. 2016, 21, 438-449. [CrossRef] [PubMed]

147. Klee, H.J.; Horsch, R.B.; Hinchee, M.A.; Hein, M.B.; Hoffmann, N.L. The effects of overproduction of two Agrobacterium tumefaciens T-DNA auxin biosynthetic gene products in transgenic petunia plants. Genes Dev. 1987, 1, 86-96. [CrossRef]

148. Beetham, P.R.; Kipp, P.B.; Sawycky, X.L.; Arntzen, C.J.; May, G.D. A tool for functional plant genomics: Chimeric RNA/DNA oligonucleotides cause in vivo gene-specific mutations. Proc. Natl. Acad. Sci. USA 1999, 96, 8774-8778. [CrossRef] [PubMed] 
149. Townsend, J.A.; Wright, D.A.; Winfrey, R.J.; Fu, F.; Maeder, M.L.; Joung, J.K.; Voytas, D.F. High-frequency modification of plant genes using engineered zinc-finger nucleases. Nature 2009, 459, 442-445. [CrossRef] [PubMed]

150. Schouten, H.J.; Jacobsen, E. Cisgenesis and intragenesis, sisters in innovative plant breeding. Trends Plant Sci. 2008, 13, 260-261. [CrossRef] [PubMed]

151. Cong, L.; Ran, F.A.; Cox, D.; Lin, S.; Barretto, R.; Habib, N.; Hsu, P.D.; Wu, X.; Jiang, W.; Marraffini, L.; et al. Multiplex genome engineering using CRISPR/Cas systems. Science 2013, 1231143. [CrossRef] [PubMed]

152. Van de Wiel, C.C.M.; Schaart, J.G.; Lotz, L.A.P.; Smulders, M.J.M. New traits in crops produced by genome editing techniques based on deletions. Plant Biotechnol. Rep. 2017, 11, 1-8. [CrossRef] [PubMed]

153. Altpeter, F.; Springer, N.M.; Bartley, L.E.; Blechl, A.E.; Brutnell, T.P.; Citovsky, V.; Conrad, L.J.; Gelvin, S.B.; Jackson, D.P.; Kausch, A.P.; et al. Advancing crop transformation in the era of genome editing. Plant Cell 2016, 28, 1510-1520. [CrossRef] [PubMed]

154. Fuller, D.Q.; Allaby, R. Seed dispersal and crop domestication: Shattering, germination and seasonality in evolution under cultivation. Annu. Plant Rev. 2009, 38, 238-295. [CrossRef]

155. Jenkins, E.S.; Paul, W.; Coupe, S.A.; Bell, S.J.; Davies, E.C.; Roberts, J.A. Characterization of an mRNA encoding a polygalacturonase expressed during pod development in oilseed rape (Brassica napus L.). J. Exp. Bot. 1996, 47, 111-115. [CrossRef]

156. Petersen, M.; Sander, L.; Child, R.; van Onckelen, H.; Ulvskov, P.; Borkhardt, B. Isolation and characterisation of a pod dehiscence zone-specific polygalacturonase from Brassica napus. Plant Mol. Biol. 1996, 31, 517-527. [CrossRef] [PubMed]

(C) 2018 by the authors. Licensee MDPI, Basel, Switzerland. This article is an open access article distributed under the terms and conditions of the Creative Commons Attribution (CC BY) license (http://creativecommons.org/licenses/by/4.0/). 